\title{
Pharma fines increase, but the pain is not felt on Wall Street
}

The US government tries to wield a big stick to deter pharmaceutical companies from offlabel drug promotion: market a product for a use not authorized by the country's Food and Drug Administration and you could get hit with a massive fine. Just last year the pharmaceutical giant GlaxoSmithKline (GSK) had to pay $\$ 3$ billion to the US government for inappropriate marketing of its antidepressants Paxil (paroxetine) and Wellbutrin (bupropion) and for failing to disclose key safety information about the diabetes drug Avandia (rosiglitazone).

Yet the power to prosecute companies for off-label drug promotion was threatened last month by a federal appeals court ruling in New York (see page 1).

In that case, the judges overturned the conviction of a sales representativepreviously found guilty of selling a drug approved only for narcolepsy as a

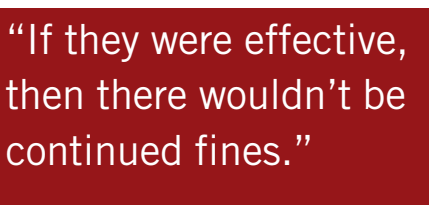

analysis conducted by Nature Medicine of the companies' stock prices leading up to and after the public announcement of the government's punishment found that, although the fines seem to have caused a slight dip in stock prices, the impact was not long lasting (see 'The fine line').

\section{Parsing penalties}

"These fines are intended to be symbolic to a certain extent," says Brandon Garrett, who studies corporate crime at the University of Virginia School of Law in Charlottesville. The penalties might help boost the public's confidence in government regulators, but, given the lack of a long-term impact on stock price, these monetary damages do little to push companies to truly crack down on off-label promotion. "If they were effective, then there wouldn't be continued fines," says treatment for insomnia, fibromyalgia and other conditions-on the grounds that such marketing represented a constitutionally protected form of free speech. The decision applies in only New York, Connecticut and Vermont, but experts anticipate the legal battle will find its way to the US Supreme Court.

If the ruling is upheld, many fear it could open the floodgates to drug companies promoting their wares on only the flimsiest of medical evidence. Already, some health policy experts say that there needs to be more, not less, done to rein in off-label pedaling. "Even though the fines are large amounts of money to consumers, they're not large amounts of money to corporations," says Adriane Fugh-Berman, a pharmacologist at the Georgetown University Medical Center in Washington, DC, who studies pharmaceutical marketing practices. The lawsuits do tarnish the pharmaceutical companies' reputations, she says, particularly in the eyes of the public, but there is still concern that many firms see the fines as a mere cost of doing business. They don't hit drugmakers' bottom line, and thus they haven't served as a practical tool to incentivize better practices.

Take, for example, GSK's recent \$3 billion penalty and similar hefty fines levied against New Jersey's Merck for off-label promotion of the pain reliever Vioxx (rofecoxib) and Illinois's Abbott Laboratories for misbranding the seizure medication Depakote (divalproex). An
Boston also recently showed that such fines can have the unintended consequence of encouraging more off-label drug prescription for a particular class of agents. Chace's team looked at Medicaid claims after a 2004 agreement by New York-based Pfizer to pay $\$ 430$ million for improper promotion of the antiepileptic drug Neurontin (gabapentin). In the year that followed, Neurontin's market share dropped $28 \%$ but the use of competing anticonvulsants for the off-label treatment of bipolar disorder went up 13\% (J. Clin. Psychiatry 73, 1388-1394, 2012).

Most experts think that, rather than increasing the size of ineffective fines, deterrents to off-label marketing need to move beyond monetary retributions. In the 2012 case against Abbott, part of the settlement included forced changes to how the company reimburses salespeople for their work. Fugh-Berman also proffers that the government could cut off Medicare and Medicaid reimbursement to companies that disobey the marketing laws, and Chace suggests limiting the length of time a patent is protected.

Ultimately, however, the government's options are limited-and they could become more limited if the recent legal decision is upheld. Like banks that are 'too big to fail' without hurting the public, Garrett notes that most major drug companies are simply too big to lose their licenses, as this would hurt consumers reliant on their live-saving medications.

Susan Matthews

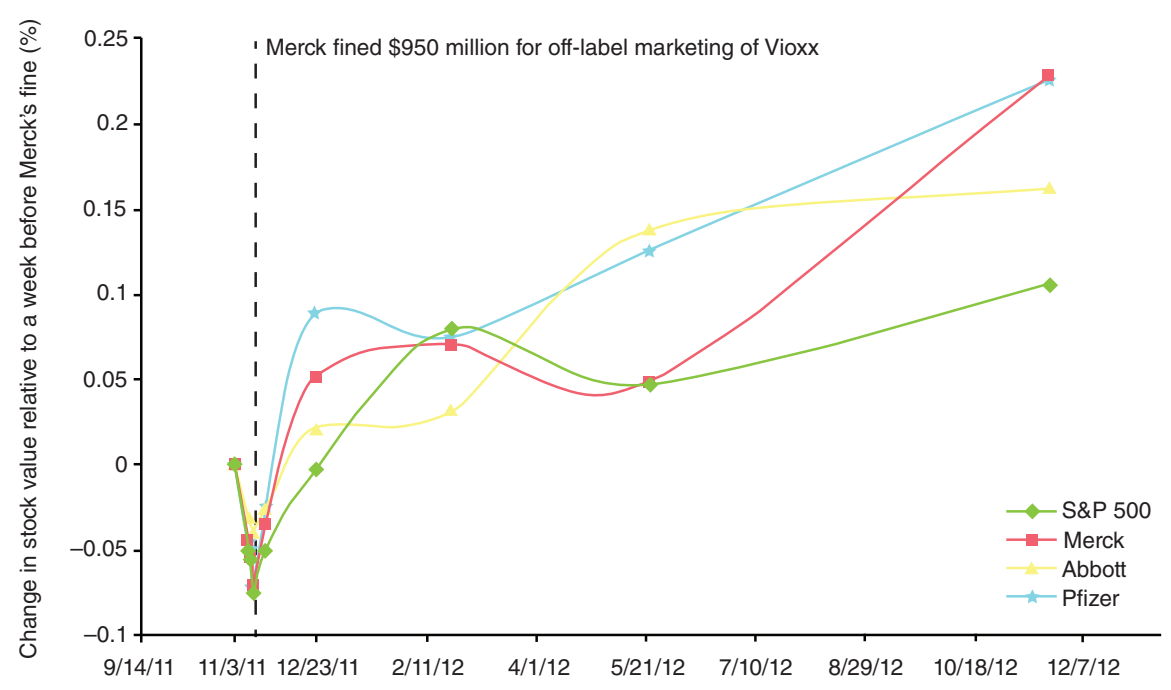

The fine line: Pharma cuts a fine figure, despite penalties for off-label marketing . 